Uncovering Divergence: Management Attitudes towards HRM

Practices and Works Council Presence in German SMEs

First Author:

Dr. Markus Helfen, Freie Universität Berlin (helfen@zedat.fu-berlin.de)

Second Author:

Elke S. Schuessler, Freie Universität Berlin (elke.schuessler@fu-berlin.de)

DRAFT April 2008

Final Version in Economic and Industrial Democracy 


\title{
Uncovering Divergence: Management Attitudes towards HRM Practices and Works Council Presence in German SMEs
}

\begin{abstract}
This paper examines the impact of management attitudes towards human resource management (HRM) practices on the presence of works councils in German small and medium-sized enterprises (SMEs). Based on a survey among executives of German SMEs, the key result of a logit regression analysis is that managers' attitudes towards key HRM practices have a strong impact on the prevalence of the works council in German SMEs. In particular, positive management attitudes towards individual employee participation and direct supervision seem to be detrimental for the institutionalization of works councils. The results suggest that there is more diversity and management choice regarding the institutions of industrial relations than generally expected in the case of German firms.
\end{abstract}

Keywords: German industrial relations, human resource management, management attitudes, strategic choice, de-institutionalization, small and medium-sized enterprises 
"(...) there are always two kinds of people: those who think that there are always two kinds of people and those who don't." (cited in Sorge, 1991: 161)

\section{Two Types of Erosion in the German System of Industrial Relations}

The debate on the changes in the German system of industrial relations (IR) revolves mainly around the issue of whether decentralization will undermine the German model by changing the balance of power between management and employees (e.g. Frege, 2003; Weitbrecht, 2003). Whilst some observers concentrate on the slow erosion of the German model, traditionally characterized by the separation of collective bargaining at the industry and codetermination at the workplace level (Baethge \& Wolf, 1995; Keller, 1998; Hassel, 1999), others stress its relative stability (Streeck, 1997; Thelen, 2000; Frege, 2003).

Due to its bias towards Germany's large publicly listed corporations where the traditional IR institutions are almost universally established, this debate has, until recently, overshadowed the study of a somewhat different phenomenon: the high number of small and medium-sized firms (SMEs) not covered by any form of collective interest representation (GumbrellMcCormick \& Hyman, 2006: 479). Such a "co-determination free zone" is generally populated by SMEs in the service sector and in industries with precarious employment conditions (Addison et al., 1997; Abel \& Ittermann, 2003; Gumbrell-McCormick \& Hyman, 2006).

Although the peculiarities of interest representation in SMEs seem to be common knowledge, quantitative research on the topic has so far neglected to explicitly examine subjective rather than structural factors accounting for the lower coverage of SMEs by IR institutions (for exceptions see Dilger, 2002: 168; Jirjahn \& Smith, 2006). In particular, subjective factors such as management attitudes towards HRM policy have been neglected. On a theoretical level, this neglect might be due to the fact that most observers of the German case tend to see little opportunity for managers to unilaterally opt out of collective arrangements, as HRM 
strategies are seen to be severely restricted by the presence of macro-level institutions like codetermination laws (Katz \& Darbishire, 2000; Gumbrell-McCormick \& Hyman, 2006).

In contrast to this argument, we maintain that SMEs do have significant informal choice when it comes to the compliance with or avoidance of IR institutions at the micro level, even in a formally regulated institutional environment like Germany (Oliver, 1991; Schnabel \& Wagner, 1996: 301). In this context, we focus on the works council as the critical case for two reasons. First, as argued by Addison et al. (2000: 286), the mandatory nature of the works council does not mean it is established automatically. Employees still need to choose to elect one and can thus be influenced indirectly by management. Second, it should be expected that the works council is met with less open resistance than collective bargaining with its distributional impact on firms' profits, as the works council is legally obliged to interact with management on the basis of mutual trust and in the interest of the company.

We begin our argument with a critique of the traditional view that German workplace relations are characterized by a stable pattern of high-quality employment or a joint teambased approach (e.g. Katz \& Darbishire, 2000). We will then examine the extent of the representation gap in the German SME sector and account for how and why German SMEs may choose to avoid works councils. In particular, we go beyond established explanations and argue that management attitudes towards HRM practices can either impede or support the establishment of a works council. In the empirical section, we test this argument by applying a logit regression model. We observe that managers' support of individual employee participation and the use of supervisors for the coordination and control of work are detrimental to the establishment of works councils. These results suggest that there is more diversity on the micro-level regarding the institutions of IR than previously expected for the case of German firms. 


\section{Convergence vs. Divergence Revisited: Stable German Workplace Relations?}

Traditionally, the German IR system has impressed many observers by its stability, as well as by its contributions to competitiveness, high wages, and a low level of industrial disputes (Streeck, 1997; Hassel, 1999). From a bird's eye view, this stability rests on the dual system of interest representation, i.e. the separation of collective bargaining between unions and employer associations at the industry level from co-determination at the enterprise level (Baethge \& Wolf, 1995). The works council is hereby considered as a pillar of stability for employment relations in general.

The argument that individualistic HRM practices such as individual employee involvement may be used as a union exclusion strategy by employers - as is the case in the United States or the United Kingdom - has been neglected in the German context (Katz \& Darbishire, 2000; Weitbrecht, 2003; Gumbrell-McCormick \& Hyman, 2006). If new workplace practices are introduced, so the story goes, the works council is involved as a negotiating partner, based on being granted exclusive co-determination rights that reach far beyond the information and consultation rights of employees in other European countries (Behrens, 2003: 56). The institutional complementarity between the German qualification system and the works council is additionally said to limit German firms' ability to restructure towards an individualistic approach (Sorge \& Streeck, 1988; Marsden, 2000; Katz \& Darbishire, 2000: 184). Consequently, in Katz \& Darbishire's famous typology of workplace practices, German firms are located within a "joint team-based" pattern that is distinguished from "low-wage" or "HRM" patterns by its relatively high degree of employee representation limiting the amount of divergence by negotiation among social partners (Katz \& Darbishire, 2000: 175).

Counter to these claims, we consider the traditional characterization of German workplace relations as problematic because it overlooks two critical points. First, although workplaces with at least five employees must establish a works council if such a council is requested by 
the workforce or the respective union, the majority of German firms does not have a works council, albeit falling under the co-determination law. Second, German employers do have different options of circumventing formal regulations, but because direct employee participation and co-determination are usually described as going hand-in-hand (e.g. Katz \& Darbishire, 2000:10), these are largely underestimated.

With respect to our first argument, we only need to highlight the numbers. The 1990s are described as a period of dramatic change in German IR (Hassel, 1999; Thelen, 2000: 145). Nearly unanimous findings reveal that an increasing number of firms are neither covered by a collective bargaining agreement nor has a works council. This share has increased from 30 percent in 1997 to over 47 percent in 2003 in West Germany. In East Germany, the erosion of traditional institutions of IR has been even more pronounced with the share of enterprises without works council and collective wage agreement having risen from 47 percent in 1997 to 67 percent in 2003 (Bellmann et al., 1998: 61; Ellguth \& Kohaut, 2004: 454). Recent studies report a share of 11 percent of firms having a works council in both parts of Germany, which means that approximately 54 percent of all employees were not represented in 2005 (Ellguth, 2007: 156). The share of employees covered by collective bargaining has dropped to 50 percent in East Germany and 64 percent in West Germany, compared to 58 and 74 percent respectively in 1998 (Schnabel et al., 2006: 170; Ellguth, 2007: 157).

Regarding our second argument, we maintain that there are several options for management to circumvent institutional pressures and demands for conformity (Oliver, 1991: 152), thereby increasing the divergence in workplace relations. In particular, management has the opportunity to informally choose deviant behavior to reduce the scope of formal institutions without actually having to attack these institutions openly. In terms of Oliver's theoretical alternatives for responding to institutional pressure, manipulation and avoidance strategies are proposed as informal ways of resistance. Whereas concealing nonconformity, buffering, or escaping from institutional rules are three strategies to avoid conformity, manipulation is 
defined as “(...) the purposeful and opportunistic attempt to co-opt, influence, or control institutional pressures (..)” (Oliver, 1991: 157). With regard to the regulatory framework of German IR, we argue that there is considerable leeway for SMEs to cope with institutional pressure, particularly by using the tactics of buffering and manipulation.

\section{Is There A Representation Gap in German SMEs?}

The strong case for German firms' institutional conformity to the regulatory environment is rooted in studies of large firms in traditional sectors such as telecommunications, automobiles, or chemicals, where the traditional institutions of IR are well established (Katz \& Darbishire, 2000: 200 and 208). Hyman (1996: 629), however, argues that in actuality different realities exist in workplace relations, particularly in smaller firms. If we focus more closely on the distribution of works councils along the standard size classes used in research on SMEs (Günterberg \& Kayser, 2004: 22), one observes that in 2003 only 7 percent of firms below 50 employees has a works council; this is in contrast to nine out of ten firms with more than 500 employees (see Table 1). In terms of employees covered, recent figures for the year 2005 reveal that only 12 percent of the workforce in firms with 5 to 50 employees was represented by a works council. In firms with 50 to 100 and 100 to 200 employees, this share ranged between 47 and 68 percent (Ellguth, 2007: 156).

\section{INSERT TABLE 1 ABOUT HERE}

To grasp the extent of a possible representation gap, one has to combine the data on works council prevalence with employment figures. SMEs make up the vast majority of firms in Germany and represent about 85 percent of the German workforce. For the year 2003, Federal Agency data reported at total of 1.9 million small establishments with up to 50 employees in Germany, which represent approximately 90 percent of all local firm units and employ 10.9 million workers subject to social security contributions. That accounts for approximately 46 percent of the German workforce in regular employment. Approximately 4 percent of all 
establishments can be found in the medium-sized category between 50 to 500 employees, representing 9.0 million people or 39 percent of the workforce. Only 4,281 or 0.2 percent of all German firm units do employ more than 500 people, although these companies represent 21 percent of the entire workforce (Günterberg \& Kayser, 2004: 22). In short, we observe lower coverage rates in the dominant part of the employment structure, illustrating that employees in SMEs are indeed affected by a representation gap.

The arguments that are usually put forth to explain this structural difference are based on the assumption that SMEs, on average, compete predominantly on the basis of unit labour costs and thus have several incentives for preventing a works council, such as avoiding distributional losses and retaining flexibility (Addison et al., 2000: 286; Schnabel \& Wagner, 2001: 460), protecting a more direct flow of information between management and employees (Gumbrell-McCormick \& Hyman, 2006: 480), and curbing time-consuming political bargaining in decision-making (Addison et al., 1997: 436). Whatever the specific reasons might be, we consider German SMEs as a permanent source of institutionally deviant management behavior vis-à-vis the formal institutions of IR.

\section{Management Ideologies and Workplace Relations in SMEs}

Large and small firms differ not only with respect to sheer numbers, but also with regard to the quality of workplace relations. Using Oliver's framework of tactics regarding regulatory and institutional pressures, we argue that the tactics of buffering and manipulation are deployed by SMEs to prevent employees from establishing a works council. Buffering refers to the decoupling of internal processes from formal structures and external contact to reduce the possibility of external control and evaluation whilst maintaining the legitimacy of the organization (Oliver, 1991: 155). Within our context, owner-managers of SMEs might, for example, be able to communicate an employee-oriented HR policy to external constituencies, thereby reducing the likelihood of being scrutinized by external actors like unions or new 
employees. Manipulation tactics, in contrast, are overtly directed towards changing institutionalized expectations by manipulating the criteria of acceptable practices or performance (Oliver, 1991: 158). In the case of workplace relations, measures of direct participation can be understood as a device to manipulate employees' beliefs about the necessity of employer-independent representation. Whether or not these strategies are utilized by SMEs is likely to depend on management attitudes towards specific HRM practices and towards interest representation in general.

Following the pioneering work of Kotthoff, several qualitative studies of employment relations in German SMEs have shown that the quality of the employment order („betriebliche Sozialordnung“) does not only depend on the formal regulation of the works constitution, but also on the attitudes and beliefs of actors regarding each other and the relationships they would like to see established (Trinczek, 1989: 447; Osterloh, 1993: 183; Kotthoff, 1994: 275; Frege, 2003). Management attitudes were therefore found to exert a rather strong influence on work relations (Trinczek, 1989: 453; Kotthoff, 1994: 327; Kotthoff, 1998: 79).

Using these findings, one can identify at least two generic management ideologies concerning employee integration. First, management can oppose any form of employee voice and insist on its decision-making prerogative. Second, management can take a more cooperative stance and concede that employees should have their say in work-related issues (Kotthoff, 1979: 247; Osterloh, 1993: 271; Kotthoff, 1994: 63). These ideologies typically correspond with distinguishable attitudes regarding HRM practices. Particularly in SMEs, morally justified HRM practices are prominent, in which managers aim to provide voice informally. According to Kotthoff (1994: 320), in such a quasi-paternalistic employment order works councils - if present - are typically either reduced to an "extended arm" of management or are isolated from decision-making altogether. 
This observation corresponds to a long standing critique of an ideological component in HRM strategies, ranging from the "hard" variant of HRM concentrating on cost effectiveness and performance to the "soft" version emphasizing "high-trust relationships, with scope for employees to exercise influence" (Hendry, 1995; Weitbrecht, 2003). In critical accounts of HRM practices it is frequently argued that these practices are used to justify other HR activities like downsizing or increasing flexibility. Managers might only pretend to involve employees via practices of direct participation, or they might actually believe in these practices but still live a workplace culture of management control (Guest, 1987: 519; Guest, 2001: 100f.; Colvin, 2003: 380). HRM - even in its "soft" variety - might merely be a management technique to obscure the real divisions between employers and employees through ideological manipulation (Grahl \& Teague, 1991; Legge, 2001).

Although we concede that direct participation and representative co-determination may have a common aim in integrating employees by involving them in company decisions, they clearly differ in terms of their democratic, representative and binding character. Practices such as direct participation and teamwork are granted by management and can be withdrawn again unilaterally (Hauser-Ditz et al., 2006b: 504). Some observers assume that direct participation might in most cases not actually be withdrawn in order to prevent works council formation (Hauser-Ditz et al., 2006a: 365) or to prevent frustration among employees triggered by the violation of the informal rules of the employment contract (Rousseau \& McLean Parks, 1993: 35), but it usually provides a more hollow form of interest representation without codetermination rights (e.g. Hauser-Ditz et al., 2006b). Moreover, it is doubtful whether employers may simply be motivated by reputation alone, and self-binding, informal commitments of employers are thus particularly vulnerable to unilateral violation (Frick \& Sadowski, 1995: 66). In contrast, the works councils' legitimacy rests upon the law, guaranteeing at least relative autonomy to works councils' decision-making procedures. At the core of the matter, a rather neo-paternalistic mode of HRM culture in SMEs stands against 
a democratically legitimized and regulated mode of collective interest representation of employees through the works council.

\section{Management Attitudes towards HRM Practices and Works Council Presence}

Given that different HRM practices are either beneficial or detrimental to formally guaranteed employee voice, we expect managers' attitudes towards HRM practices to have an impact on the prevalence of the works council as a formal device for employee voice. We maintain that such attitudes mirror the dominant management ideology regarding work relations in SMEs, and that they may contain a manipulative component to avoid organizing attempts by employees. To develop our framework of management attitudes towards HRM practices, we draw on three important areas of HRM commonly identified by the HRM literature (Tichy et al, 1982; Fossum, 1984; Beer et al., 1985; Baron \& Kreps, 1999; Katz and Darbishire, 2000): managerial involvement and responsibility, the coordination and control of work, and career development and skills. Whilst some of these attitudes may be compatible with having a works council as an independent form of interest representation, others are not. Pay policy, another frequently mentioned dimension, was excluded from our framework for two reasons: one component of pay policy, management pay, already serves as a control variable in our analysis, and we are not able to distinguish different pay systems for regular employees on the basis of our data. To summarize, we focus on three dimensions of HRM practices that are heuristically derived from different strands in the HRM literature and look at the subjective assessment of these HRM practices by management and its effect on the formal representation of employees by works councils. The three dimensions will be outlined below.

\section{Attitudes towards Managerial Involvement and Responsibility}

The first dimension examines managers' statements about their involvement in strategic decision-making and their rewards, considering that the degree and type of managerial 
involvement is frequently described as one of the most important dimension of an HRM strategy (Tichy et al., 1982: 59; Baron \& Kreps, 1999: 27).

Managers who stress their involvement in strategic decisions and innovation are typically representatives of "high involvement" workplaces with a culture of high employee qualification and participation in major decisions. According to the argument of Katz and Darbishire (2000), this type of involvement in the decision-making process is a central feature of the joint team-based model, which can be associated with a combination of direct and representative participation of employees. As a consequence, it is likely that an emphasis on involvement in strategy and innovation for managers goes hand-in-hand with formal employee representation at the operational level.

Hypothesis 1a: If managers consider strategy and innovation as their main responsibility, a firm is more likely to have a works council.

In contrast, managers that stress their responsibility for customer relations and believe in promotion based on their individual performance might be representative of a more individualistic employment system with managerial discretion and informal procedures (Katz \& Darbishire, 2000: 10). A customer-oriented management may be less geared towards longterm employee development and involvement and, as a consequence, should be associated with a reduced likelihood to observe a works council. Similarly, one subjective component of managerial involvement is the opportunity to improve one's career by individual performance (Tichy et al., 1982: 53). We address individual managers' beliefs about the role that individual performance plays for their promotion within the firm. We expect a positive attitude towards promotion by individual performance as negatively associated with operational employees' involvement in the form of a works council. 
Hypothesis 1b: If managers are responsible for customer relations and believe that they are promoted on the basis of individual performance, a firm is less likely to have a works council.

\section{Attitudes towards the Coordination and Control of Work}

The second dimension looks at the role of supervisors and the degree of formality in the control and coordination of work, a factor often addressed in the HRM literature (Baron \& Kreps, 1999: 22).

Managers responsible for the coordination and control of work might be interested primarily in smooth operations in the value creation process (Fitzroy \& Kraft, 1987: 495; Freeman \& Kleiner, 1990: 352). Considering that stable work processes depend on the cooperation of employees, managers are more willing to compromise with employees' interests and prefer institutionalized procedures of interest bargaining. A similar conclusion can be drawn from traditional accounts of IR institutions, in which collective IR institutions are complementary to a Fordist work organization. In a Fordist work organization, a pronounced division of labor, hierarchical organizational structures, and a reliance on supervisory personnel for control are accompanied by an intermediary interest representation of employees through trade unions or works councils. Such an interest intermediation ensures the exclusion of labor conflicts from operations at the workplace level, supported by a codification of legally binding rules by law (for an early version of this argument see Dahrendorf, 1959: 257).

Hypothesis 2a: If managers support the role of supervisory personnel for the coordination and control of work and prefer standardized work procedures and processes, a firm is more likely to have a works council.

During the 1990s, individual employee participation has gained prominence in the debates on HRM and employment patterns, notably in the context of so-called high-performance workplaces and strategies of labor flexibility (Katz \& Darbishire, 2000: 269; Kalleberg, 2001: 
482). In order to increase the innovative capacity and flexibility of a firm, management aims to break the barriers of Fordist and bureaucratic work organization by reducing hierarchical layers, delegating tasks to employees, and enlarging their decision-making autonomy (Jürgens et al., 1993: 377; Minssen, 1999: 133). On the level of individual employees, a direct participative management practice uses elements of job enrichment and enlargement, i.e. vertical and horizontal task integration, to increase employee discretion regarding their work (Jürgens et al., 1993: 372; Frick, 2002: 87). As argued above, in German SMEs with a small number of hierarchical layers, such measures have already been used for a long time, albeit in a more paternalistic mode. By introducing or preserving HRM practices of individual employee participation, the traditional IR institutions might be of minor relevance as they are not perceived as a necessary means to give employees a voice (Fossum, 1984: 348f.; Minssen, 1999: 142; Colvin, 2003: 380).

Hypothesis 2b: If managers support individual employee participation, a firm is less likely to have a works council.

\section{Attitudes towards Career Development and Skills}

Finally, the skills dimension examines the recruitment and career development systems, as well as the general type of skills required by an organization. According to all approaches of HRM, recruitment of individuals with apt skills and career development can be regarded as part of the core of any HRM strategy (Hendry, 1995: 6; Tichy et al., 1982: 51; Baron \& Kreps 1999: 404).

As previously argued, different scholars have elaborated the idea that German firms in particular are characterized by an employment system based on highly-qualified employees (Sorge \& Streeck, 1988: 25f.; Marsden, 2000: 345). Following the idea of diversified quality production, i.e. the production of specialized products of high quality in relatively large volumes, a firm's HRM policy relies more on internal labor flexibility than on adjustments of 
the employment level via the external labor market. Organizationally, such an HRM policy is based on production processes which combine a high degree of mechanization, flexible working time arrangements and highly qualified employees, trained by a firm-based vocational training system and promoted accordingly (Sorge \& Streeck, 1988: 27; Thelen, 2004: 48). The presence of a works council can be regarded as being complementary to this kind of employment system for several reasons: not only does the works council provide reliable mechanisms to give employees a voice, but it also opens communication channels to those employees in control of the critical stages of production, thereby rationalizing employment relations (Marsden, 2000: 345).

Hypothesis 3: If managers believe in a high qualification strategy, favor professional career development, or support recruitment by clearly defined tasks, a firm is more likely to have a works council.

\section{Data and Results}

The data used in this article is based on a postal survey among German CEOs and personnel managers in 2001/2002 titled “Organizational and Personnel Development Today”. Because the survey had an exploratory character investigating the HRM characteristics of young, fastgrowing firms, it was comprised of over 50 questions and covered an extensive range of management topics from innovation management to HRM. The questionnaires were completed by business owners, executive managers, or HR managers. The survey was comprised of a number of questions concerning structural firm characteristics such as the industry or profit situation, and on managers' attitudes towards the HRM practices in their firms. About 15,000 questionnaires were sent out, and approximately 5.5 percent were returned. With this method cross-section data from 819 German companies with 261,000 employees was obtained. Sample selection for the 15,000 addresses was done via one of the most encompassing data collections of postal mail addresses of German business firms, 
hosted by Creditreform, a German credit inquiry agency. Besides the high coverage of German firms (3.6 million data points), the decisive advantage of this address data is the option to pre-select cases by defined criteria, so it was possible to target small and mediumsized firms (see Creditreform 2008).

Table 2 summarizes the sub-sample’s demographic characteristics and the relevant variables for our analysis. The sub-sample's structural characteristics such as firm size or age can be considered as roughly representative of German SMEs. Our independent variable is the presence of a works council in the firm. The exact wording of the question was "Does your firm have a works council?” In the entire sample, we observe 264 firms (32.9 percent) that do have a works council if we exclude the smallest firms below the five-employee threshold. The firms without a works council account for the remaining 67.1 percent of the sample. One aspect needs some emphasis: with approximately 81.2 percent, most of the works councils can be found in companies with 5 to 500 employees. Due to missing information and exclusion of firms under 5 employees and firms over 500 employees, 486 cases enter our subsample for the following logit analysis. However, we can say that the 486 cases entering our analysis have a similar share of firms with a works council (31.6 percent) as the total sample (32.9 percent); the difference is due to exclusion of firms with 500 employees and more.

\section{INSERT TABLE 2 ABOUT HERE}

\section{Measuring Management Attitudes towards HRM Practices}

Empirically, we are focusing on managers' statements about the HRM practices in their organization. We have therefore selected several statements that express managers' attitudes towards different HRM practices in their organization. Rather than directly describing the reality of HRM in their organization, we assume that these statements express managers' attitudes and beliefs about what constitutes good HRM practice, thereby expressing the firm's prevailing human relations ideology. Next, we have structured the statements according to the 
three dimensions of our framework. In doing so, we favor a heuristically motivated grouping of relevant items and refrain from constructing another typology of "ideal types" of HRM practices on empirical grounds, as Katz \& Darbishire (2000) have done. In doing so, we are well aware that our approach is not encompassing enough to capture all relevant factors and that it is eclectic regarding the many dimensions discussed in the literature on employment systems. But these are shortcomings common to most typologies of this kind (Hendry, 1995; Baron \& Kreps, 1999; Marsden, 1999; Katz \& Darbishire, 2000; Baron et al., 2001; for an overview within the German context see Wächter, 2002).

Our study is largely justified by the novelty of our research. By assessing management attitudes towards important HRM practices and their potential impact on the type and quality of interest representation, we disclose some of the details that are usually neglected in quantitative research on works councils. Frege (2003) takes a similar approach, but looks at the attitudes of works councilors. Dilger (2002) and Jirjahn and Smith (2006) have a different focus and are therefore less specific with respect to the impact of management attitudes on interest representation.

\section{Attitudes towards Managerial Involvement and Responsibility (H1)}

Each point discussed in the following paragraphs was measured on a five-point Likert scale ranging from either "disagree absolutely” to "agree absolutely" or from "not relevant at all” to "very relevant". To measure the degree and type of managerial involvement and the corresponding management attitudes we selected three items. To assess the influence of a managerial involvement in strategy and innovation, we looked at managers' scores on the statement "I have responsibility for goals, strategies and innovation to shape the firm's future" (H1a). The overwhelming majority of managers within our sub-sample, 87.5 percent, consider contributions to innovation and strategy as their main responsibility. To assess the influence of customer orientation, we used the statement "I am responsible for actively managing 
customer relations” (H1b). Again, a majority of 63.8 percent ranked the relevance of this management task high or very high. To measure managers’ belief in promotion by individual performance, we used the statement "I have the opportunity to distinguish myself though performance and hard work" (H1b). In total 365 managers see the relevance of individual performance as high or very high in their firm, indicating on average a strong belief in promotion through individual performance.

\section{Attitudes towards the Coordination and Control of Work (H2)}

To measure management attitudes towards the coordination and control of work, we selected three statements. First, the statement "Work processes and functions are formally defined and clearly documented" is considered as an indicator for management attitudes towards a formalized, Fordist work organization (H2a). Accordingly, 36.4 percent of the managers agreed or strongly agreed with this statement, indicating a rather low relevance of processoriented task definitions in managers' mindsets on work organization. Second, the statement “Supervisors coordinate and control work processes”, measures managers’ attitudes regarding the role of supervisors in work organization $(\mathrm{H} 2 \mathrm{a})$. A vast majority of managers prefer supervisory control and coordination of work, as is shown by a share of 71.4 percent of managers agreeing to this statement. Third, the statement "The coordination and control of work is the sole responsibility of individual employees" provides us with a hint towards managers' attitudes regarding employee involvement on an individual level (H2b). Most managers seem reluctant to lay the coordination and control of work in the hands of individual employees, as only 19.3 percent of the managers agreed or strongly agreed with this statement.

\section{Attitudes towards Career Development and Skills (H3)}

Finally, the third dimension of HRM practices is measured by three items representing management attitudes towards career development and skills. The first statement "Our firm 
has a systematic program for executive development” indicates whether a firm relies on a professional internal labor market. Only 16.6 percent of managers agreed or strongly agreed with this statement, indicating a minor role of systematic career development in SMEs. The second statement "New employees must show high intellectual potential and skills which can be deployed in complex work assignments” indicates how far managers are oriented towards a high-skill culture of workplace relations. A total of 51.2 percent, a slight majority, agreed with this statement. This percentage reveals one source of diversity in German SMEs because German firms' employment relations are usually expected to rely heavily on skilled employees. The third statement "New employees must show skills that match exactly defined tasks” measures managers’ attitudes towards clear role assignments in a more bureaucratically structured workplace. Again, a majority of 51.8 percent of managers agreed with this statement.

\section{Control Variables}

To investigate attitudinal determinants of SMEs' coverage by works councils, economic conditions and several other structural characteristics of the workplace relations in a firm should be taken into account as control factors. Regarding firm size, we control for the wellestablished fact that the probability of works councils increases with company size. Small enterprises show the lowest percentage of SMEs with a works council, as was demonstrated above. To measure firm size, the number of employees is used. Firms with 5 to 50 employees represent the vast majority in the sub-sample (61 percent), whereas firms up to 500 employees have a share of 39 percent. The average firm has 69 employees.

A firm's probability of having a works council is also affected by the industry in which a firm operates. Firms in the traditional segments of German manufacturing, for example, are more likely to have a works council than firms in the service industry. As a proxy for industryspecific forms of interest representation, the standard classification of industries from official 
business statistics is used. The sub-sample consists of SMEs from the metal industry (32.2 percent of the sample), the chemical industry including natural resources (14.4 percent), the traditional service industries of construction, transport and utilities (20.9 percent), retail and wholesale trade including financial services (18.4 percent) and business related services including information, communication, and software services as well as consultancy and engineering (14.0 percent).

Similarly, the presence of a works council depends on the region in which a firm operates (Kädtler et al., 1997), as West German IR institutions are still comparatively new to East German firms and may thus be less institutionalized in East than in West German SMEs (Schroeder, 2000; Artus, 2001). The distinction between West and East Germany is measured by a dummy indicator variable for East Germany. A total of 19.7 percent of the firms in our sub-sample are located in the Eastern part of Germany.

Regarding a firm's history, one might argue that firms are likely to reproduce the form of interest representation that was prominent at the time of their founding (Baron et al., 2001: 962; Hauser-Ditz et al. 2006a). We therefore distinguish four different founding periods by dummy indicator variables. In the first period between 1949 and 1969 (26.7 percent of the SMEs in the sample), the institutions of IR met broad legitimacy as they set the rules of the game for negotiation between "social partners” (Schroeder, 2000: 391). In the following two decades from 1970 to 1989, German IR institutions showed relative stability, albeit with different signs. In the 1970s (13.1 percent of the SMEs in the sample), even a regulatory extension of co-determination at the company level passed its way through legislation. Beginning in the late 1970s and the early 1980s, partly due to the economic crisis at that time, the first signs of an erosion of collective bargaining at the industry level are detected (Streeck, 1995: 321; 26.9 percent of the SMEs in the sample). Contrary to the first three periods, companies founded since 1990 have been established during a time of crisis for IR institutions. These firms make up for 33.2 percent of the SMEs in the sample. 
The influence of the profit situation of a firm on the dissemination of works councils has been pointed out by various studies (Freeman \& Lazear, 1995: 29; Pull, 1996: 168; Addison et al., 1997). As long as a good firm performance mitigates the potential for labor conflicts, the demand for formal procedures of conflict resolution might be reduced because a firm may offer better working and employment conditions. Consequently, a firm in good economic condition is less likely to have a works council. The profit situation is measured by a dummy indicator which rates SMEs as having a good profit situation if they have been operating for at least three years (between 1998 and 2002) at an annual profit. As Table 2 shows, 71.7 percent of the SMEs in our sub-sample report a good profit situation. Conversely, a situation marked by economic loss and shrinkage might force management to reduce wages or jobs, thereby increasing the potential for labor-related conflicts. Since employees who might face a dismissal are much more likely to organize collectively, a negative economic situation increases the probability of a firm having a works council (Freeman \& Kleiner, 1990: 353). The extent of personnel problems is approximated by executives' agreement to the statement "Staffing level of the firm is too high". In total, 40.7 percent of the respondents deny any serious problems with the staffing level of their firm, 17.3 percent report that they have such problems, leading to an average assessment that personnel problems are not very severe.

Next, we control for differences in the governance structure between small and large firms. Contrary to the salaried managers of large enterprises, the owner-managers of SMEs might feel more responsible for their employees while at the same time being more reluctant to share decisions rights with them, thus revealing some kind of paternalism. As discussed above, in such a social ordering owner-managers are regularly engaged in informal practices to give employees a voice, but only within the limits of their authority to avoid restrictions placed on their decision rights (Kotthoff, 1994: 327; Addison et al., 2000: 288). We therefore conclude that founder-led SMEs are less likely to have a works council. The management role of founders in a firm is captured by a dummy indicator for majority ownership, namely the 
founder's share of above 50.0 percent of a firm's capital. Defined accordingly, 358 SMEs or approximately 73.5 percent of the sub-sample are founder-controlled.

Additionally, the realignment of management and owner interests is important as argued by the principal-agent literature (Jirjahn, 2003: 410). If salaried managers earn flexible pay according to firm performance, they are expected to behave similar to owners. Studies investigating performance-related pay report it to decrease (albeit not always significantly) the likelihood of a works council (Addison et al., 1997; Addison et al., 2000; Schnabel \& Wagner, 2001; Jirjahn, 2003). To test the impact of management's incentives on the existence of a works council, we use a dummy indicator for managers that do receive flexible pay. With 35.0 percent of the respondents in the sub-sample, a third of the managers report incentive pay of this form.

Although works councils are formally independent from unions, the relationship between the two institutions is usually very close (Streeck, 1995; Traxler, 1995; Schnabel \& Wagner, 1996). In works council elections, the majority of successful candidates are union members (usually around 70 percent; Behrens, 2003). Moreover, union officials supply works councils with information and expertise (Müller-Jentsch, 1995: 61). If works councils are tightly coupled with trade unions, it becomes very likely that external pressure from trade unions positively influences the establishment of works councils. The membership of a firm in an employer association serves as our proxy for the strength of the trade union because it can be assumed that a firm is more likely to join an employer association, if a firm's workforce is well organized (Traxler, 1995; Schnabel \& Wagner, 1996). In our sub-sample, around 62.8 percent of the SMEs are members of an employer association.

\section{Management Attitudes towards HRM Practices and Works Councils: A Logit Analysis}

So far the discussion has revealed some peculiarities with regard to German managers' attitudes towards several HRM practices. To identify the impact of management attitudes 
toward HRM practices on the presence of a works council in SMEs more closely, we now turn to regression analysis. As an estimation technique we use a standard logit model which offers the possibility to estimate the influence of a set of explanatory firm characteristics $\left(\mathrm{x}_{\mathrm{ij}}\right)$ on a nominally-scaled dependent variable (y) by maximum likelihood estimation (Long, 1997: 148). Equation (1) contains the logit model we test for the presence of a works council in a firm:

(1) $\ln ($ odds $)=\sum_{\mathrm{j}=1}^{\mathrm{J}} \beta_{\mathrm{j}} \cdot \mathrm{X}_{\mathrm{ij}}=\sum_{\text {controls }} \beta_{\text {controls }} \cdot \mathrm{X}_{\mathrm{i}, \text { controls }}+\sum_{\mathrm{HRM}} \beta_{\mathrm{HRM}} \cdot \mathrm{X}_{\mathrm{i}, \mathrm{HRM}} \cdot$

The set of control variables ( $\mathrm{x}_{\text {control }}$ ) is composed of a firm's size, regional origin, founding period, profit situation, personnel problems, industry, owner control, management incentives and our trade union proxy. The variables to be tested particularly in the context of managers' attitudes regarding HRM practices $\left(\mathrm{x}_{\mathrm{HRM}}\right)$ include the three dimensions of our framework: attitudes regarding managerial involvement, attitudes regarding the coordination and control of work, and attitudes regarding career development and skills. The parameter estimates $(\beta)$ indicate the change of the natural logarithm of the odds. A positive or negative sign indicates a positive or a negative influence on the probability of a works council. The regression results are shown in Table 4.

Before estimation results can be discussed, the correlation matrix of the independent variables provides a quick control for linear relations among the regressors. Table 3 shows this correlation matrix with correlations indicated by a star if significant at the 5 percent level. Only one third (84) of the 253 entries in the cells of Table 3 show a significant partial correlation coefficient. Table 3 also indicates that there are no serious problems with high correlation coefficients (Kennedy 2003: 209). There are obvious negative correlations between our dummy variables for the industry distinction and founding cohorts. Two exceptions must be mentioned: the "managerial involvement in strategy and innovation" 
variable shows relatively high correlation coefficients $(0.48$ and 0.41$)$ with the two other indicators for attitudes on managerial involvement, customer orientation and individual performance orientation. This could be interpreted as some sort of collinearity among these indicators (s. Table 3). To account for this problem, we discuss separate models for each of the theoretically derived dimensions of our framework in the estimations section (see also Table 5 in the Appendix).

INSERT TABLE 3 ABOUT HERE

\section{Results for the Control Factors}

Regarding the control variables, our results largely support the findings from previous studies (s. Table 4). As already known, firm size has a strong positive effect on the presence of a works council. Interestingly, the distinction between East and West Germany does not display a negative effect; this result might partly be due to the fact that data were collected ten years after reunification, and partly due to the control of other firm characteristics such as the founding period. With respect to the industry effects, our findings confirm that the service sector, retail and wholesale trade in particular, is the most hostile environment for works councils. The founding periods show that firms founded before 1960 are most likely to have a works council, at least compared to the reference category of firms founded between 1990 and 2002. However, in the founding period between 1970 and 1990 no significant difference can be observed (s. Table 4). As expected, a good profit situation reduces the likelihood of observing a works council in a firm, whereas severe personnel problems, i.e. a high staffing level, increase the presence of a works council. Finally, the variables on founder and management control, as well as on the influence of unionization on works council presence, show the expected signs and are significant. Firms under the control of owners and with a management incentive system based on firm performance are detrimental to works council establishment. Contrary to that, unionization has a positive effect on works councils, given 
one accepts the assumption that a firm's membership in an employer association reflects a high degree of unionization in the firm. Overall, the combined control effects represent a fairly good model of works council presence in German firms between 5 and 500 employees, as is indicated by a McFadden $\mathrm{R}^{2}$ of 0.28 .

\section{INSERT TABLE 4 ABOUT HERE}

\section{Results for the Attitudinal Variables}

The explicative power of the model can be increased significantly if one takes managers' attitudes towards HRM practices into account. McFadden $\mathrm{R}^{2}$ is increased from 0.28 to 0.33 if these indicators are integrated into the model (see model summary and tests at the end of Table 4). This supports our argument that managements' adversarial stance can have a strong effect on works council presence and should be added to explanations of SMEs' coverage by IR institutions. If management attitudes towards HRM practices do make a difference, one can conclude that the qualitative or ideological component of workplace relations in SMEs can tip the balance in favor of, or against the establishment of a works council. Not all of the indicators, however, show a significant effect.

Regarding the hypotheses about managers' attitudes towards managerial involvement in their organization (H1), we see that managers who stress innovation and long-term strategy are associated with a positive effect on works council presence. This attitude thus seems to be complementary to worker representation via the works council. Contrary to that, managers who stress the customer orientation of their organization are negatively associated with works council presence, indicating an adverse relationship between customer orientation and works council presence in SMEs. Both results confirm our expectation, based on the assumption that managerial involvement in innovation and strategy is typical for firms with a hightechnology, high-skill employment system, whereas responsibility for customer relations typically goes along with avoidance of a works council. Interestingly, however, the measure 
of individual performance orientation did not show a significant effect, even though the association was still negative. This might be due to the fact that managers in most SMEs feel that they will be promoted based on their individual performance, and hence the item might not be indicative of any specific attitude regarding employee representation.

However, as was already mentioned in the brief discussion of the correlation matrix, we might have some problems of collinearity in the measurement of the items for managerial involvement. Therefore, we have conducted separate models for each of our dimensions and report the results of these estimations in the Appendix (Table 5). These results reveal that the model improvement by adding the dimension of managerial involvement alone is not significant and that parameter estimates only leave the positive effect of the innovation and strategy variable as weakly significant. This leads us to conclude that the impact of managerial involvement on works council presence is not as strong as we expected. As a consequence, we believe the link between management attitudes regarding their own position within the firm and management activities for, or against the presence of a works council to be rather weak. This weakness of the managerial involvement dimension, however, points to the importance of our second and third dimensions, dealing directly with management attitudes towards the organization of work.

Regarding the hypotheses about the coordination and control of work (H2), the strongest effect can be observed for the role of supervisory personnel. SMEs whose managers believe in supervisory coordination and control seem to form a more hostile environment for the collective organization of employees. This contradicts our hypothesis that such a workplace practice should be compatible with formal worker representation in German SMEs (H2a). One potential explanation for this result is that middle managers want to protect their role as mediators between workers and top management, and thus actively try to avoid a "sandwich position", in which employees communicate directly with the top. A different explanation would invoke the union animus of managers and owners of SMEs alike, aggressively tackling 
early organization attempts of employees. Similarly, and in support of our second hypothesis (H2b), practices stressing individual employee involvement in the coordination and control of work are detrimental to the founding of works councils, although on a lower significance level. A more de-personalized style of the coordination and control of work by rules and definitions, as was hypothesized to be characteristic for Fordist bureaucracies, reveals a weakly significant, positive effect in the complete model of Table 4.

Again, some qualifications are necessary with respect to the additional tests we conducted (see Table 5 in the Appendix). Here we can observe that the overall model improvement of the addition of the items on coordination and control proves to be significant. When taken alone, however, the coordination and control of work by defined processes and tasks is revealed to be highly significant, whereas the effects of the attitudes on the role of supervisors and individual employee control fade. Besides the potential disturbances produced by the items on managerial involvement this finding casts some doubt on the relative weight of the different characteristics of work control. In particular, managers in favor of a more depersonalized and regulated work coordination might also exhibit a friendly attitude towards the procedures of collective interest representation by works councils, a fact particularly likely in the upper level of our sample's size range. Katz and Darbishire (2000) describe a similar pattern with what they call a "Japanese-oriented" workplace practices.

According to our findings, management attitudes regarding career development and skills (H3) seem to be an important factor for works council presence. This finding is further underlined by the variant additionally tested for the career development and skills dimension alone, as is indicated by the highly significant model improvement for this category of variables (see Table 5 in the Appendix). Indeed, in the complete model all three indicators show a positive sign, albeit on different significance levels. In the complete model, the strongest effect can be observed for a strong belief in high skills as is documented by the recruitment of new employees based on their intellectual capacity. A positive attitude of 
managers towards a professional career development within the firm, an indicator for internal labor markets with stable employment patterns and career ladders, is also positively associated with works council presence. Both results show up in the estimation in Table 5 again. The less significant, but also positive effect of the belief in a pre-defined fit between an employee and his position in the firm can be interpreted again as a hint that rule-based, Fordist work organizations might be complementary to the collective interest representation in form of a works council. However, this finding is not confirmed in the additional estimation (see Table 5 in the Appendix), but shows up again in the estimation model without the managerial involvement dimension. This indicates that the coordination and control of work and career development and skill concerns are relevant control factors for each other.

\section{Discussion and Conclusions}

Based on a quantitative dataset, our analysis provides information about what is happening within German firms on a more qualitative dimension of workplace relations. Our focus on the attitudes of managers regarding several HRM practices enabled us to go beyond traditional explanations of works council presence. In our view, such an analysis represents a necessary addition to the research on works council determinants presented to date, as it provides a necessary step towards integrating subjective, qualitative and ideological factors in the quantitative research literature on German IR.

If we link our findings back to other typologies of employment relations and systems, we can propose to add managers' attitudes as an additional source of divergence in employment systems, an aspect which has been neglected in the discussion mainly centered on formal institutions and structural variables so far. The implication of our findings for convergencedivergence arguments is twofold. First, to understand trends in employment regimes, one has to look at managers' attitudes about what constitutes good workplace practices before one can conclude that workplace relations will converge to a dominant pattern, for the reason that 
such attitudes play a role in the dissemination of formal institutions. Second, and somewhat related to the first point, de-institutionalization could be the result of a misfit between deviant ideologies - whatever their source - and extant institutions in a given national context. If considered from this viewpoint, formal IR institutions do not only shape workplace relations and IR cultures as is usually expected in the case of Germany (Hyman, 1996; Katz \& Darbishire, 2000), but management's beliefs and ideologies about what constitutes good practice can conversely become one source of de-institutionalization.

This view is supported if one pays attention to the areas in which formal IR institutions have not been fully institutionalized. These areas are inhabited by institutionally diverging firms that represent a permanent source of deviant management ideologies. In particular, our argument is important for the discussion of high-performance work systems because these are based on the ideology of individual employee involvement, customer orientation, and high skill levels. The mixed results on these practices show that it remains unclear if such management orientations can actually alter the German model radically (Guest, 2001; Legge, 2001). In particular, we cannot claim that workplace representation has shifted in a lasting and sustainable way from collective rule-making to plant-level voluntarism, accompanied by performance-related measures of HRM and by introducing direct employee participation (Baethge \& Wolf, 1995).

From our viewpoint, however, individual employee participation might be better understood as a manipulative management ideology to increase labor productivity and firm profitability, while at the same time decoupling the firm from the costs associated with IR institutions. Böhm and Lücking's (2006) classification of managerial ideologies seems to support this interpretation in Germany. Furthermore, the discussion on individual employee participation in what is commonly understood as the "HRM model" (cf. Katz \& Darbishire, 2000) has neglected the strong belief of managers in supervising the coordination and control of work. This means that there are at least two ideological sources of management deviation from co- 
determination laws: a "supervisory control pattern" and an "individual involvement pattern". Management practices following from such beliefs might either deter employees in SMEs from organizing themselves for fear of being penalized, or make employees believe in a modern-sounding performance culture rendering collective interest representation unnecessary. Our findings thus indicate and at least partially explain the existing divergence in workplace practices even in face of the homogenous regulatory environment in Germany.

Of course, much remains to be done to settle these questions definitely. As a first step in this direction we propose to take a closer look at competing management ideologies, their outcome for employees, and the possible reactions of employee representatives. We further suggest collecting longitudinal data on a qualitative basis in order to assess the stability of the forms of employee involvement once they have been put in place. As we have focused on managerial attitudes and not actual practices, we suggest collecting information directly from employees. This step seems to be necessary to assess the HRM practices that are actually in place and to contrast potential results with the dominant management ideology in a given firm. Finally, we propose both, a qualitative refinement of existing HRM typologies and a quantitative testing of these typologies, as a very fruitful pathway for further research. 


\section{Notes}

The authors wish to thank Martin Behrens for commenting on earlier drafts of the paper and gratefully acknowledge the financial support of the German BMBF (Research Grant No. 01HL0011 "Work and employment in fast-growing enterprises"). 


\section{References}

Addison, J.T., Schnabel, C. and Wagner, J. (1997) 'On the Determinants of Mandatory Works Councils in Germany', Industrial Relations 36(4): 419-445.

Addison, J.T., Schnabel, C. and Wagner, J. (2000) 'Die mitbestimmungsfreie Zone aus ökonomischer Sicht', Hamburger Jahrbuch für Wirtschaft und Gesellschaft 45: 277-292.

Artus, I. (2001) Krise des deutschen Tarifsystems. Die Erosion des Flächentarifvertrags in Ost und West. Wiesbaden: Westdeutscher Verlag.

Baron, J.N., Burton, M.D. and Hannan, M.T. (2001) 'Labor Pains: Change in Organizational Models and Employee Turnover in young, high-tech Firms', American Journal of Sociology 106(4): 960-1012.

Baron, J. N. and Kreps, D. M. (1999) Strategic Human Resource Management. Frameworks for General Managers. Hoboken: Wiley.

Bäthge, M. and Wolf, H. (1995) 'Continuity and Change in the 'German model' of Industrial Relations', Ch. 8 in R. Locke, T. Kochan and M. Piore (eds) Employment Relations in a Changing World Economy. Cambridge, Mass.: MIT Press.

Beer, M., Spector, B., Lawrence, P. R., Mills, D. Q. and Walton, R. E.. (1985): Human Resource Management - A General Manager's Perspective - Text and Cases, New York \& London: Free Press.

Behrens, M. (2003) 'The New German Works Constitution Act in Practice', WSI Mitteilungen 56 (2): 56-65.

Bellmann, L., Ellguth, P. and Seifert, H. (1998) 'Weiße Flecken in der Tarif- und Mitbestimmungslandschaft', Die Mitbestimmung 44(11): 61-62.

Böhm, S. and Lücking, S. (2006) 'Orientierungsmuster des Managements in betriebsratslosen Betrieben - Zwischen Willkürherrschaft und Human Resource Management', pp. 107-139 in I. Artus, S. Böhm, S. Lücking and R. Trinczek (eds) Betriebe ohne Betriebsrat. Informelle Interessensvertretung in Unternehmen. Frankfurt a. Main, Campus.

Colvin, A.J.S. (2003) 'Institutional Pressures, Human Resource Strategies, and the Rise of Non-Union Dispute Resolution Procedures', Industrial and Labor Relations Review 56(3): 375-392.

Creditreform (2008) 'Firmendaten (B2B)', www.creditreform.de $4^{\text {th }}$ January, 2008, www.creditreform.de/Deutsch/Creditreform/Produkte_und_Leistungen/Firmen-

_und_Personendaten/Firmendaten/index.jsp.

Dahrendorf, R. (1959) Class and class conflict in industrial society. London: Routledge.

Dilger, A. (2002) Ökonomik betrieblicher Mitbestimmung. Die wirtschaftlichen Folgen von Betriebsräten. München: Rainer Hampp Verlag.

Ellguth, P. (2007) 'Betriebliche und überbetriebliche Interessenvertretung - Ergebnisse aus dem IAB Betriebspanel', WSI Mitteilungen 60(3): 155-157.

Ellguth, P. and Kohaut, S. (2004) 'Tarifbindung und betriebliche Interessenvertretung: Ergebnisse des IAB-Betriebspanels 2003', WSI-Mitteilungen 57(8): 450-454.

Fitzroy, F.R. and Kraft, K. (1987) 'Efficiency and Internal Organization: Works Councils in West German Firms', Economica 54: 493-504. 
Fossum, J.A. (1984) 'Strategic Issues in Labor Relations', pp. 343-360 in C.J. Fombrun, N.M. Tichy and M.A. Devanna (eds) Strategic Human Resource Management. New York: Wiley.

Freeman, R.B. and Lazear, E.P. (1995) 'An Economic Analysis of Works Councils', pp. 27-52 in J. Rogers and W. Streeck (eds) Works Councils: Consultation, Representation and Cooperation in Industrial Relations. Chicago: University of Chicago Press.

Freeman, R.B. and Kleiner, M.M. (1990) 'Employer Behavior in the Face of Union Organizing Drives', Industrial and Labor Relations Review 43(4): 351-365.

Frege, C.M. (1999) Social Partnership at Work: Workplace Relations in Post-Unification Germany. London: Routledge.

Frege, C.M. (2003) 'Transforming German Workplace Relations: Quo Vadis Cooperation?', Economic and Industrial Democracy 24(3): 317-347.

Frick, B. (2002) "High Performance Work Practices' und betriebliche Mitbestimmung: Komplementär oder substitutiv? Empirische Befunde für den deutschen Maschinenbau', Industrielle Beziehungen 9(1): 79-102.

Frick, B. and Sadowski, D. (1995) 'Works Councils, Unions, and Firm Performance', pp. 4681 in: F. Buttler (ed.) Institutional frameworks and labor market performance, London: Routledge.

Grahl, J. and Teague, P. (1991) 'Industrial Relations Trajectories and European Human Resource Management', pp. 67-91 in C. Brewster and S. Tyson (eds) International Comparisons in Human Resource Management. London: Pitman.

Guest, D. (1987) 'Human Resource Management and Industrial Relations', Journal of Management Studies 24(5): 503-521.

Guest, D. (2001) 'Industrial Relations and Human Resource Management', pp. 96-113 in J. Storey (ed.) Human Resource Management - A Critical Text. London: Thomson Learning.

Guenterberg, B. and Kayser, G. (2004) 'SMEs in Germany. Facts and Figures', Institut für Mittelstandsforschung, Bonn, IfM-Materialien 161.

Gumbrell-McCormick, R. and Hyman, R. (2006) 'Embedded Collectivism? Workplace relations in France and Germany', Industrial Relations Journal 37(5): 473-491.

Hassel, A. (1999) 'The Erosion of the German System of Industrial Relations', British Journal of Industrial Relations 37(3): 483-585.

Hauser-Ditz, A., Hertwig, M. and Pries, L. (2006a) 'Betriebsräte und "Andere Vertretungsorgane". Verbreitung und Kontext betrieblicher Beschäftigtenvertretungen in der deutschen Privatwirtschaft', Industrielle Beziehungen 13(4): 340-369.

Hauser-Ditz, Hertwig, M. and Pries, L. (2006b) 'Betriebsräte und andere Vetretungsorgane im Vergleich - Strukturen, Arbeitsweisen und Beteiligungsmöglichkeiten', WSI Mitteilungen 59(9): 500-506.

Hendry, C. (1995) Human Resource Management: A Strategic Approach to Employment. Oxford: Butterworth-Heinemann.

Hyman, R. (1996) 'Institutional Transfer: Industrial Relations in Eastern Germany', Work, Employment and Society 10(2): 601-639.

Jirjahn, U. (2003) 'Executive Incentives, Works Councils and Firm Performance', Schmollers Jahrbuch 123(3): 397-421. 
Jirjahn, U. and Smith, S. C. (2006) 'What factors lead management to support or oppose employee participation - with and without works councils? Hypotheses and evidence from Germany', Industrial Relations 45(4): 650-680.

Jürgens, U., Malsch, T. and Dohse, K. (1993) Breaking from Taylorism. Changing Forms of Work in the Automobile Industry. Cambridge: Cambridge University Press.

Kädtler, J., Kottwitz, G. and Weinert, R. (1997) Betriebsräte in Ostdeutschland: Institutionenbildung und Handlungskonstellationen 1989-1994. Opladen: Westdeutscher Verlag.

Kalleberg, A.L. (2001) 'Organizing Flexibility: The Flexible Firm in a New Century', British Journal of Industrial Relations 39(4): 479-504.

Katz, H. and Darbishire, O. (2000) Converging Divergences: Worldwide Changes in Employment Systems. Ithaca: ILR Press.

Keller, B. (1998) 'Recent Shifts in Public Policy and Industrial Relations', pp. 61-74 in R. Hoffmann, O. Jacobi, B. Keller and M. Weiss (eds) German Industrial Relations under the Impact of Structural Change, Unification and European Integration. Düsseldorf: HansBöckler-Stiftung.

Kennedy, P. (2003) A Guide to Econometrics. Cambridge: MIT Press.

Kotthoff, H. (1979) Betriebsräte und Betriebliche Herrschaft. Eine Typologie partizipativer Handlungsformen und Deutungsmuster von Betriebsräten und Unternehmensleitungen. Freiburg: Campus.

Kotthoff, H. (1994) Betriebsräte und Bürgerstatus. Wandel und Kontinuität betrieblicher Mitbestimmung. München: Rainer Hampp Verlag.

Kotthoff, H. (1998) 'Mitbestimmung in Zeiten interessenpolitischer Rückschritte: Betriebsräte zwischen Beteiligungsofferten und 'gnadenlosem Kostensenkungsdiktat", Industrielle Beziehungen 5(1): 76-100.

Legge, K. (2001) 'Silver Bullet or Spent Around? Assessing the Meaning of the 'High Commitment Management'/Performance Relationship', pp. 21-36 in J. Storey (ed.) Human Resource Management - A Critical Text. London: Thompson.

Long, J.S. (1997) Regression Models for Categorical and Limited Dependent Variables. Thousand Oaks: Sage.

Marsden, D. (1999) A Theory of Employment Systems: Micro-Foundations of Societal Diversity. Oxford: Oxford University Press.

Marsden, D. (2000) 'A Theory of Job Regulation, the Employment Relationship, and the Organisation of Labour Institutions', Industrielle Beziehungen 7(4): 320-347.

Minssen, H. (1999) 'Direkte Partizipation contra Mitbestimmung? - Herausforderung durch diskursive Koordinierung', pp. 129-156 in W. Müller-Jentsch (ed.) Konfliktpartnerschaft Akteure und Institutionen der industriellen Beziehungen. München: Rainer Hampp Verlag.

Müller-Jentsch, W. (1995) 'Germany: From Collective Voice to Co-Management', pp. 53-78 in J. Rogers and W. Streeck (eds) Works Councils: Consultation, Representation, and Cooperation in Industrial Relations, Chicago: University of Chicago Press.

Oliver, C. (1991) 'Strategic Responses to Institutional Processes', Academy of Management Review 16(1): 145-179.

Osterloh, M. (1993) Interpretative Organisations- und Mitbestimmungsforschung. Stuttgart: Schäffer-Poeschel. 
Pull, K. (1996) Übertarifliche Entlohnung und freiwillige betriebliche Leistungen. München: Rainer Hampp Verlag.

Rousseau, D.M. \& McLean Parks, J. (1993): 'The Contracts of Individuals and Organizations', Research in Organizational Behavior 15: 1-43.

Schnabel, C. and Wagner, J. (1996) 'Ausmaß und Bestimmungsgründe der Mitgliedschaft in Arbeitgeberverbänden: Eine empirische Untersuchung mit Firmendaten', Industrielle Beziehungen 3(4): 293-306.

Schnabel, C. and Wagner, J. (2001) 'Verbreitung und Bestimmungsgründe verschiedener Formen der Arbeitnehmerpartizipation in Industriebetrieben', Industrielle Beziehungen 8(4): 445-462.

Schnabel, C., Zangelmeyer, S. and Kohaut, S. (2006) 'Collective Bargaining Structure and its Determinants: An Empirical Analysis with British and German Establishment Data', European Journal of Industrial Relations 12(2): 165-188.

Schroeder, W. (2000) Das Modell Deutschland auf dem Prüfstand. Zur Entwicklung der industriellen Beziehungen in Ostdeutschland. Wiesbaden: Westdeutscher Verlag.

Sorge, A. (1991) 'Strategic fit and the societal effect: Interpreting cross-national comparisons of technology, organization and human resources', Organization Studies, 12(2): 161-190.

Sorge, A. and Streeck, W. (1988) 'Industrial Relations and Technical Change: The Case for an Extended Perspective', pp.19-47 in W. Streeck and R. Hyman (eds) New Technology and Industrial Relations. Oxford: Blackwell.

Streeck, W. (1995) 'Works Councils in Western Europe. From Consultation to Participation', pp. 314-348 in J. Roger and W. Streeck (eds) Works Councils: Consultation, Representation and Cooperation in Industrial Relations. Chicago: University of Chicago Press.

Streeck, W. (1997) 'German Capitalism: Does It Exist? Can It Survive?', New Political Economy 2(2): 237-257.

Thelen, K. (2000) 'Why German Employers Cannot Bring Themselves to Dismantle the German Model', pp. 138-169 in T. Iversen, J. Pontusson and D. Soskice (eds) Unions, Employers, and Central Banks. Macroeconomic Coordination and Institutional Change in Social Market Economies. Cambridge: Cambridge University Press.

Thelen, K. (2004) How Institutions Evolve. The Political Economy of Skills in Germany, Britain, the United States, and Japan. Cambridge: Cambridge University Press.

Tichy, N.M., Fombrun, C.J. and Devanna, M.A. (1982) 'Strategic Human Resource Management', Sloan Management Review 23: 47-60.

Traxler, F. (1995) 'Two Logics of Collective Action in Industrial Relations?', pp. 23-44 in C. Crouch and F. Traxler (eds) Organized Industrial Relations in Europe: What Future? Aldershot: Avebury.

Trinczek, R. (1989) 'Betriebliche Mitbestimmung als soziale Interaktion. Ein Beitrag zur Analyse innerbetrieblicher industrieller Beziehungen', Zeitschrift für Soziologie 18(6): 444456.

Wächter, H. (2002) 'Vielfältige Beschäftigungsmuster - einfältige Personalwirtschaftslehre?'. Zeitschrift für Personalforschung 16(4): 476-489.

Weitbrecht, H. (2003) 'Human Resource Management and Co-determination', pp. 57-79 in W. Müller-Jentsch and H. Weitbrecht (eds) The Changing Contours of German Industrial Relations. München: Rainer Hampp Verlag. 
Appendix

(INSERT TABLE 5 ABOUT HERE) 


\section{TABLES}

\begin{tabular}{|c|c|c|}
\hline Works council coverage in percent of firms with & West Germany & East Germany \\
\hline 5 to 50 employees & 7 & 7 \\
\hline 50 to 100 & 47 & 42 \\
\hline 100 to 500 & 76 & 70 \\
\hline 500 and more & 91 & 79 \\
\hline Total & 11 & 11 \\
\hline \multicolumn{2}{|c|}{ (Source: Ellguth/Kohaut 2004: 452, based on IAB works panel) } \\
\hline
\end{tabular}

[Table 1: Number of works councils by firm size in 2003]

\begin{tabular}{|c|c|c|}
\hline Variable Name & Values & $\begin{array}{c}\text { Relative } \\
\text { frequency } \\
\text { or mean } \\
(\mathrm{n}=486)\end{array}$ \\
\hline Works Council & Works council (dummy) & 0.316 \\
\hline Firm size & Number of employees (2000) & 69 \\
\hline East Germany & East Germany (dummy) & 0.197 \\
\hline \multirow{5}{*}{ Industry } & Metal and electrical industry (incl. printing, dummy) & 0.322 \\
\hline & Chemical industry (incl. natural resources, dummy) & 0.144 \\
\hline & Construction, Transport and Utilities (dummy) & 0.209 \\
\hline & Retail and Wholesale Trade (incl. financial services, dummy) & 0.184 \\
\hline & Business related services (incl. engineering, consulting dummy) & 0.140 \\
\hline \multirow{4}{*}{ Founding period } & Founded before 1950 (dummy) & 0.267 \\
\hline & Founded 1950 to 1969 (dummy) & 0.131 \\
\hline & Founded 1970 to 1990 (dummy) & 0.269 \\
\hline & Founded 1990 to 2001 (dummy) & 0.333 \\
\hline Profit situation & Three and four years with annual profit (dummy) & 0.717 \\
\hline Staffing level & $\begin{array}{c}\text { Too high a staffing level } \\
(1=\text { absolutely disagree to } 5=\text { absolutely agree })\end{array}$ & 2.197 \\
\hline Founder-led firm & Majority share of founders ( $>50$ percent of firm's capital, dum.) & 0.735 \\
\hline Management pay & Performance related pay (dummy) & 0.349 \\
\hline Association & Membership in employers' association (dummy) & 0.628 \\
\hline \multirow{3}{*}{$\begin{array}{l}\text { Management } \\
\text { attitudes towards } \\
\text { managerial } \\
\text { involvement and } \\
\text { responsibility }\end{array}$} & $\begin{array}{c}\text { Innovation and strategy } \\
(1=\text { not relevant to } 5=\text { very relevant })\end{array}$ & 4.402 \\
\hline & $\begin{array}{c}\text { Customer relations } \\
\text { (1=not relevant to } 5=\text { very relevant })\end{array}$ & 3.803 \\
\hline & $\begin{array}{c}\text { Individual performance orientation } \\
\text { (1=absolutely disagree to } 5=\text { absolutely agree) }\end{array}$ & 3.994 \\
\hline \multirow{3}{*}{$\begin{array}{c}\text { Management } \\
\text { attitudes towards } \\
\text { coordination and } \\
\text { control of work }\end{array}$} & $\begin{array}{c}\text { Documented work processes and tasks } \\
\text { (1=absolutely disagree to } 5=\text { absolutely agree) }\end{array}$ & 2.834 \\
\hline & $\begin{array}{c}\text { Control by supervisory personnel } \\
\text { (1=absolutely disagree to } 5=\text { absolutely agree) }\end{array}$ & 3.819 \\
\hline & $\begin{array}{c}\text { Control by individual employees } \\
\text { (1=absolutely disagree to } 5=\text { absolutely agree })\end{array}$ & 2.433 \\
\hline \multirow{3}{*}{$\begin{array}{c}\text { Management } \\
\text { attitudes towards } \\
\text { career } \\
\text { development and } \\
\text { skills }\end{array}$} & $\begin{array}{c}\text { Career development } \\
(1=\text { absolutely disagree to } 5=\text { absolutely agree }))\end{array}$ & 2.238 \\
\hline & $\begin{array}{c}\text { Recruitment by high intellectual potential } \\
\text { (1=absolutely disagree to } 5=\text { absolutely agree) }\end{array}$ & 3.441 \\
\hline & $\begin{array}{c}\text { Recruitment by pre-defined tasks } \\
\text { (1=absolutely disagree to } 5=\text { absolutely agree }\end{array}$ & 3.511 \\
\hline
\end{tabular}




\begin{tabular}{|c|c|c|c|c|c|c|c|c|c|c|c|}
\hline Part I & Firm size & $\begin{array}{c}\text { East } \\
\text { Germany }\end{array}$ & $\begin{array}{l}\text { Chemical } \\
\text { industry }\end{array}$ & $\begin{array}{c}\text { Constructi } \\
\text { on, etc. }\end{array}$ & Trade & $\begin{array}{l}\text { Business } \\
\text { services }\end{array}$ & $\begin{array}{c}\text { Founded } \\
\text { before } \\
1950\end{array}$ & $\begin{array}{c}\text { Founded } \\
1950 \text { to } \\
1969\end{array}$ & $\begin{array}{c}\text { Founded } \\
1970 \text { to } \\
1990\end{array}$ & $\begin{array}{c}\text { Profit } \\
\text { situation }\end{array}$ & $\begin{array}{c}\text { Staffing } \\
\text { level }\end{array}$ \\
\hline East Germany & -0.05 & & & & & & & & & & \\
\hline Chemical industry & $0.11 *$ & -0.03 & & & & & & & & & \\
\hline Construction, etc. & $-0.13^{*}$ & 0.04 & $-0.21 *$ & & & & & & & & \\
\hline Trade & -0.08 & -0.01 & $-0.20 *$ & $-0.24^{*}$ & & & & & & & \\
\hline Business services & -0.05 & -0.04 & $-0.17 *$ & $-0.21 *$ & $-0.19 *$ & & & & & & \\
\hline Founded before 1950 & $0.12 *$ & $-0.15^{*}$ & $0.18 *$ & -0.02 & 0.04 & $-0.20 *$ & & & & & \\
\hline Founded 1950 to 1969 & -0.08 & $-0.15^{*}$ & 0.02 & 0.03 & 0.04 & -0.07 & $-0.23^{*}$ & & & & \\
\hline Founded 1970 to 1990 & -0.03 & $-0.28 *$ & -0.05 & -0.03 & -0.06 & $0.09 *$ & $-0.37 *$ & $-0.23 *$ & & & \\
\hline Profit situation & 0.07 & $-0.14^{*}$ & 0.05 & 0.03 & -0.05 & 0.06 & -0.01 & -0.02 & $0.09 *$ & & \\
\hline Staffing level & 0.02 & -0.01 & $0.10 *$ & -0.03 & 0.06 & -0.07 & 0.08 & -0.01 & -0.04 & $-0.10^{*}$ & \\
\hline Founder-led firm & $-0.10 *$ & -0.06 & 0.07 & 0.08 & -0.04 & -0.05 & $-0.10 *$ & 0.07 & $0.09 *$ & 0.00 & $0.12 *$ \\
\hline Management pay & $0.22 *$ & -0.07 & 0.01 & -0.09 & -0.04 & $0.13 *$ & -0.01 & -0.01 & -0.07 & $0.16 *$ & 0.04 \\
\hline Association & $0.11 *$ & -0.01 & 0.00 & 0.07 & $0.10 *$ & $-0.12 *$ & $0.27 *$ & 0.04 & $-0.16 *$ & -0.04 & 0.07 \\
\hline Innovation and strategy & -0.04 & -0.03 & -0.01 & -0.03 & 0.03 & -0.02 & 0.00 & -0.03 & 0.01 & 0.08 & $-0.11^{*}$ \\
\hline Customer orientation & $-0.25 *$ & -0.02 & -0.04 & $0.10 *$ & -0.03 & 0.05 & $-0.12 *$ & 0.00 & 0.03 & $0.11 *$ & $-0.10 *$ \\
\hline Performance orientation & -0.03 & -0.08 & 0.04 & -0.06 & $0.09 *$ & 0.03 & 0.04 & 0.03 & 0.01 & 0.06 & -0.06 \\
\hline Documented processes & 0.05 & -0.09 & 0.01 & $-0.12 *$ & -0.04 & 0.01 & -0.07 & 0.04 & 0.07 & 0.08 & -0.09 \\
\hline Control by supervisors & 0.00 & $0.17 *$ & -0.03 & 0.08 & 0.02 & -0.04 & -0.01 & 0.00 & $-0.11 *$ & -0.06 & $-0.13 *$ \\
\hline Control by employees & -0.08 & $-0.16^{*}$ & 0.05 & -0.07 & -0.04 & $0.10^{*}$ & 0.01 & 0.02 & $0.12 *$ & -0.01 & $0.10^{*}$ \\
\hline Career development & $0.19 *$ & -0.02 & -0.05 & $-0.13^{*}$ & 0.04 & $0.12 *$ & -0.01 & -0.03 & 0.03 & 0.00 & 0.09 \\
\hline High intellectual potential & 0.02 & $0.10^{*}$ & $-0.10^{*}$ & $-0.11 *$ & 0.03 & $0.21 *$ & -0.04 & $-0.10^{*}$ & -0.05 & 0.07 & $-0.15^{*}$ \\
\hline Pre-defined tasks & 0.05 & 0.00 & 0.00 & 0.06 & -0.03 & -0.02 & -0.09 & 0.00 & 0.02 & 0.00 & 0.00 \\
\hline
\end{tabular}

[Table 3: Correlation matrix of independent variables (continued on next page)] 


\begin{tabular}{|c|c|c|c|c|c|c|c|c|c|c|c|}
\hline Part II (...) & $\begin{array}{l}\text { Founder- } \\
\text { led firm }\end{array}$ & $\begin{array}{l}\text { Manage- } \\
\text { ment pay }\end{array}$ & $\begin{array}{l}\text { Asso- } \\
\text { ciation }\end{array}$ & $\begin{array}{c}\text { Inno- } \\
\text { vation \& } \\
\text { strategy }\end{array}$ & $\begin{array}{c}\text { Customer } \\
\text { orien- } \\
\text { tation }\end{array}$ & $\begin{array}{c}\text { Perfor- } \\
\text { mance } \\
\text { orientatio } \\
n\end{array}$ & $\begin{array}{c}\text { Docu- } \\
\text { mented } \\
\text { processes }\end{array}$ & $\begin{array}{c}\text { Control } \\
\text { by super- } \\
\text { visors }\end{array}$ & $\begin{array}{c}\text { Control } \\
\text { by emplo- } \\
\text { yees }\end{array}$ & $\begin{array}{c}\text { Career } \\
\text { develop- } \\
\text { ment }\end{array}$ & $\begin{array}{c}\text { High } \\
\text { intellec- } \\
\text { tual } \\
\text { potential }\end{array}$ \\
\hline \multicolumn{12}{|l|}{$(\ldots)$} \\
\hline Management pay & $-0.10^{*}$ & & & & & & & & & & \\
\hline Association & -0.04 & 0.03 & & & & & & & & & \\
\hline Innovation and strategy & -0.07 & 0.03 & -0.03 & & & & & & & & \\
\hline Customer relations & 0.03 & -0.03 & $-0.12 *$ & $0.48 *$ & & & & & & & \\
\hline Individual performance & -0.08 & 0.03 & 0.04 & $0.41 *$ & $0.29 *$ & & & & & & \\
\hline Documented processes & 0.04 & 0.03 & -0.04 & 0.02 & -0.01 & 0.06 & & & & & \\
\hline Control by supervisors & -0.01 & -0.05 & 0.03 & $0.26^{*}$ & $0.12 *$ & $0.17 *$ & -0.05 & & & & \\
\hline Control by employees & 0.02 & 0.02 & -0.08 & $-0.09 *$ & 0.03 & -0.03 & 0.07 & $-0.28 *$ & & & \\
\hline Career development & $-0.09 *$ & $0.17 *$ & $0.11 *$ & -0.04 & -0.02 & 0.00 & $0.25 *$ & $-0.10 *$ & $0.15^{*}$ & & \\
\hline High intellectual potential & $-0.11^{*}$ & $0.09 *$ & 0.02 & $0.22 *$ & $0.19 *$ & $0.20 *$ & 0.07 & $0.17^{*}$ & 0.04 & $0.17 *$ & \\
\hline Pre-defined tasks & 0.07 & -0.06 & -0.01 & 0.07 & 0.06 & $0.16^{*}$ & $0.09 *$ & $0.17 *$ & -0.03 & 0.00 & 0.05 \\
\hline
\end{tabular}

[Table 3: Correlation matrix of independent variables (continued from previous page)] 


\begin{tabular}{|c|c|c|c|c|}
\hline $\begin{array}{l}\text { Logit Regression } \\
\text { (Dependent: Works } \\
\text { Council) }\end{array}$ & Coefficient (S.E.) & z-Value & Coefficient (S.E.) & z-Value \\
\hline Firm size & \multirow{2}{*}{$\begin{array}{c}0.981 * * *(0.173) \\
0.798 * *(0.379)\end{array}$} & 5.67 & $0.950 * * *(0.184)$ & 5.18 \\
\hline East Germany & & 2.10 & $0.945 * *(0.402)$ & 2.35 \\
\hline Chemical industry 1) & $-0.108(0.364)$ & -0.30 & $0.274(0.392)$ & 0.70 \\
\hline Construction, etc. 1), & $-0.771^{* *}(0.337)$ & -2.29 & $-0.481(0.361)$ & -1.33 \\
\hline Trade 1) & $-1.576 * * *(0.374)$ & -4.22 & $-1.713^{* * *}(0.402)$ & -4.27 \\
\hline Business services 1) & $-0.052(0.403)$ & -0.13 & $-0.076(0.435)$ & -0.18 \\
\hline Founded before 1950 2) & $1.596^{* * *}(0.386)$ & 4.14 & $1.962 * * *(0.419)$ & 4.68 \\
\hline Founded 1950 to 1969 2) & $1.764^{* * *}(0.439)$ & 4.02 & $2.275^{* * *}(0.485)$ & 4.69 \\
\hline Founded 1970 to 1990 2) & $0.483(0.408)$ & 1.18 & $0.645(0.438)$ & 1.47 \\
\hline Good profit situation & $-0.672 * * *(0.262)$ & -2.57 & $-0.862 * * *(0.283)$ & -3.04 \\
\hline Staffing level & $0.204 * *(0.096)$ & 2.12 & $0.259 * *(0.107)$ & 2.41 \\
\hline Founder-led firm & $-0.688^{* *}(0.271)$ & -2.53 & $-0.752 * *(0.294)$ & -2.56 \\
\hline Management pay & $-0.596^{* *}(0.276)$ & -2.16 & $-0.856 * * *(0.301)$ & -2.84 \\
\hline Employers' association & $1.452^{* * *}(0.287)$ & 5.07 & $1.375^{* * *}(0.305)$ & 4.50 \\
\hline Innovation and strategy & - & - & $0.352^{* *}(0.171)$ & 2.06 \\
\hline Customer orientation & - & - & $-0.265^{* *}(0.130)$ & -2.03 \\
\hline Performance orientation & - & - & $-0.159(0.133)$ & -1.20 \\
\hline Documented processes & - & - & $0.183 *(0.108)$ & 1.69 \\
\hline Control by supervisors & - & - & $-0.329 * *(0.139)$ & -2.37 \\
\hline Control by employees & - & - & $-0.195 *(0.118)$ & -1.65 \\
\hline Career development & - & - & $0.210 *(0.116)$ & 1.82 \\
\hline High intellectual potential & - & - & $0.512 * * *(0.140)$ & 3.65 \\
\hline Pre-defined tasks & - & - & $0.229 *(0.124)$ & 1.84 \\
\hline Constant & $-2.398 * * *(0.564)$ & -4.25 & $-4.351^{* * *}(1.176)$ & -3.70 \\
\hline Number of observations & \multicolumn{2}{|c|}{486} & \multicolumn{2}{|c|}{486} \\
\hline LR chi2(23) & \multicolumn{2}{|c|}{$167.32 * * *$} & \multicolumn{2}{|c|}{$207.040^{* * *}$} \\
\hline -Log likelihood & \multicolumn{2}{|c|}{219.842} & \multicolumn{2}{|c|}{199.980} \\
\hline McFadden $\mathrm{R}^{2}$ & \multicolumn{2}{|c|}{0.276} & & \\
\hline LR - test (HRM attitudes) & - & & $39.73 *$ & \\
\hline
\end{tabular}

(Note: all firms with 5 to 500 employees, sig. level: $* * * 0.01, * * 0.05, * 0.10$, standard error in parentheses, 1) compared to metal industry, 2) compared to founding between 1990 and 2001) 


\begin{tabular}{|c|c|c|c|c|c|c|c|c|}
\hline $\begin{array}{l}\text { Logit Regression } \\
\text { (Dependent: Works } \\
\text { Council), Part I }\end{array}$ & Coefficient (S.E.) & z-Value & Coefficient (S.E.) & z-Value & Coefficient (S.E.) & z-Value & Coefficient (S.E.) & z-Value \\
\hline Firm size & $0.939 * * *(0.178)$ & 5.29 & $1.005 * * *(0.176)$ & 5.71 & $0.974 * * *(0.174)$ & 5.58 & $1.015^{* * *}(0.179)$ & 5.66 \\
\hline East Germany & $0.810 * *(0.383)$ & 2.11 & $0.92 * *(0.386)$ & 2.38 & $0.805^{* *}(0.391)$ & 2.06 & $0.927 * *(0.397)$ & 2.33 \\
\hline Chemical industry 1) & $-0.072(0.368)$ & -0.20 & $0.015(0.368)$ & 0.04 & $0.049(0.377)$ & 0.13 & $0.190(0.384)$ & 0.50 \\
\hline Construction, etc. 1), & $-0.717 * *(0.339)$ & -2.12 & $-0.586 *(0.348)$ & -1.68 & $-0.724 * *(0.346)$ & -2.10 & $-0.567(0.358)$ & -1.58 \\
\hline Trade 1) & $-1.569 * * *(0.376)$ & -4.17 & $-1.539 * * *(0.381)$ & -4.04 & $-1.736 * * *(0.387)$ & -4.49 & $-1.707 * * *(0.396)$ & -4.32 \\
\hline Business services 1) & $0.003(0.404)$ & 0.01 & $0.186(0.414)$ & 0.45 & $-0.370(0.425)$ & -0.87 & $-0.124(0.434)$ & -0.29 \\
\hline $\begin{array}{c}\text { Founded before } \\
19502)\end{array}$ & $1.594 * * *(0.391)$ & 4.08 & $1.747 * * *(0.394)$ & 4.43 & $1.775^{* * *}(0.404)$ & 4.39 & $1.930 * * *(0.412)$ & 4.68 \\
\hline $\begin{array}{c}\text { Founded } 1950 \text { to } \\
19692)\end{array}$ & $1.817^{* * *}(0.446)$ & 4.08 & $1.858^{* * *}(0.449)$ & 4.14 & $2.046^{* * *}(0.461)$ & 4.44 & $2.146 * * *(0.473)$ & 4.54 \\
\hline $\begin{array}{c}\text { Founded } 1970 \text { to } \\
19902)\end{array}$ & $0.489(0.413)$ & 1.18 & $0.497(0.417)$ & 1.19 & $0.587(0.423)$ & 1.39 & $0.610(0.432)$ & 1.41 \\
\hline Good profit situation & $-0.654 * *(0.264)$ & -2.47 & $-0.775 * * *(0.270)$ & -2.87 & $-0.767 * * *(0.271)$ & -2.83 & $-0.882 * * *(0.279)$ & -3.16 \\
\hline Staffing level & $0.212^{* *}(0.098)$ & 2.17 & $0.220 * *(0.010)$ & 2.23 & $0.243^{* *}(0.103)$ & 2.36 & $0.263^{* *}(0.106)$ & 2.49 \\
\hline Founder-led firm & $-0.657 * *(0.275)$ & -2.39 & $-0.772 * * *(0.277)$ & -2.79 & $-0.693 * *(0.280)$ & -2.47 & $-0.776 * * *(0.287)$ & -2.70 \\
\hline Management pay & $-0.609 * *(0.279)$ & -2.18 & $-0.678 * *(0.283)$ & -2.39 & $-0.770 * * *(0.292)$ & -2.64 & $-0.813^{* * *}(0.297)$ & -2.73 \\
\hline $\begin{array}{l}\text { Employers' } \\
\text { association }\end{array}$ & $1.429 * * *(0.288)$ & 4.97 & $1.484 * * *(0.293)$ & 5.06 & $1.405^{* * *}(0.296)$ & 4.75 & $1.395 * * *(0.303)$ & 4.60 \\
\hline$(\ldots)$ & $(\ldots)$ & $(\ldots)$ & $(\ldots)$ & $(\ldots)$ & $(\ldots)$ & $(\ldots)$ & $(\ldots)$ & $(\ldots)$ \\
\hline
\end{tabular}

[Table 5: Model variants and LR-Tests (continued on next page)] 


\begin{tabular}{|c|c|c|c|c|c|c|c|c|}
\hline $\begin{array}{l}\text { Logit Regression } \\
\text { (Dependent: Works } \\
\text { Council), Part II }\end{array}$ & Coefficient (S.E.) & z-Value & Coefficient (S.E.) & z-Value & Coefficient (S.E.) & z-Value & Coefficient (S.E.) & z-Value \\
\hline$(\ldots)$ & $(\ldots)$ & $(\ldots)$ & $(\ldots)$ & $(\ldots)$ & $(\ldots)$ & $(\ldots)$ & $(\ldots)$ & $(\ldots)$ \\
\hline $\begin{array}{c}\text { Innovation and } \\
\text { strategy }\end{array}$ & $0.290 *(0.158)$ & 1.83 & - & - & - & - & - & - \\
\hline Customer orientation & $-0.167(0.120)$ & -1.40 & - & - & - & - & - & - \\
\hline $\begin{array}{c}\text { Performance } \\
\text { orientation }\end{array}$ & $-0.070(0.124)$ & -0.57 & - & - & - & - & - & - \\
\hline $\begin{array}{l}\text { Documented } \\
\text { processes }\end{array}$ & - & - & $0.272 * * *(0.099)$ & 2.76 & - & - & $0.191 *(0.106)$ & 1.80 \\
\hline $\begin{array}{l}\text { Control by } \\
\text { supervisors }\end{array}$ & - & - & $-0.183(0.120)$ & -1.53 & - & - & $-0.301^{* *}(0.133)$ & -2.27 \\
\hline $\begin{array}{l}\text { Control by } \\
\text { employees }\end{array}$ & - & - & $-0.142(0.109)$ & -1.31 & - & - & $-0.208 *(0.115)$ & -1.80 \\
\hline Career development & - & - & - & - & $0.245^{* *}(0.106)$ & 2.30 & $0.179(0.113)$ & 1.58 \\
\hline $\begin{array}{c}\text { High intellectual } \\
\text { potential }\end{array}$ & - & - & - & - & $0.398^{* * *}(0.126)$ & 3.15 & $0.455^{* * *}(0.132)$ & 3.45 \\
\hline Pre-defined tasks & - & - & - & - & $0.194(0.119)$ & 1.64 & $0.223 *(0.122)$ & 1.83 \\
\hline Constant & $-2.802 * * *(0.876)$ & -3.20 & $-2.246^{* *}(0.902)$ & -2.49 & $-5.065^{* * *}(0.884)$ & -5.73 & $-4.215^{* * *}(1.065)$ & -3.96 \\
\hline $\begin{array}{c}\text { Number of } \\
\text { observations }\end{array}$ & 486 & & 486 & & 486 & & 486 & \\
\hline LR chi2 (df) & $171.16^{* * *}$ & & $178.39 * * *$ & & $189.46^{* *}$ & & $199.98^{* * *}$ & \\
\hline -Log likelihood & 217.921 & & 214.30 & & 208.77 & & 203.51 & \\
\hline McFadden $\mathrm{R}^{2}$ & 0.282 & & 0.294 & & 0.312 & & 0.330 & \\
\hline $\mathrm{LR}$ - test (df) & 3.84 (3) & & $11.07^{* *}$ & & $22.15^{* *}$ & & $32.67 * * *$ & \\
\hline
\end{tabular}

[Table 5: Model variants and LR-Tests (continued from previous page)] 